\title{
Detection of promoter hypermethylation in serum samples of cancer patients by methylation-specific polymerase chain reaction for tumour suppressor genes including $R U N X 3$
}

\author{
SING-HUANG TAN ${ }^{1 *}$, HIROSHI IDA ${ }^{2 *}$, QUEK-CHOON LAU ${ }^{3}$, BOON-CHER GOH ${ }^{1}$, \\ WEI-SHIENG CHIENG ${ }^{1}$, MARIE $\mathrm{LOH}^{4}$ and YOSHIAKI ITO ${ }^{2}$
}

\author{
${ }^{1}$ Department of Hematology-Oncology, 5 Lower Kent Ridge Road, National University Hospital, Singapore 119074; \\ ${ }^{2}$ Institute of Molecular and Cell Biology, Molecular Oncology Laboratory, 61 Biopolis Drive, Proteos, Singapore 138673; \\ ${ }^{3}$ Ngee Ann Polytechnic, School of Life Sciences and Chemical Technology, 535 Clementi Road, Singapore 599489; \\ ${ }^{4}$ Bioinformatics Institute, 30 Biopolis Street, No. 07-01 Matrix, Singapore 138671, Republic of Singapore
}

Received April 5, 2007; Accepted May 16, 2007

\begin{abstract}
The purpose was to validate the use of $R U N X 3$ as a potential biomarker for detection of cancer in serum samples and to determine its sensitivity alone and in combination with p16, RASSF $1 A$ and $C D H 1$ using methylation-specific polymerase chain reaction (MSP). We examined the promoter methylation status of $R U N X 3, p 16, R A S S F 1 A$ and $C D H 1$ by MSP using the serum of 70 metastatic breast, non-small cell lung, gastric, pancreatic, colorectal or hepatocellular carcinomas. The DNA from 10 healthy serum controls was used to determine the specificity of methylation. According to our results, promoter hyper-methylation of RUNX3 was detected in the serum of 44 patients comprising breast $9 / 19$ (47\%), non-small cell lung 11/20 (55\%), gastric 4/4 (100\%), pancreatic $2 / 2(100 \%)$, colorectal $11 / 17(65 \%)$ and liver $7 / 8$ (88\%) carcinomas. Comparative figures for the other genes were as follows: p16 - 39/70 (7/19, 10/20, 2/4, 0/2, 12/17, 8/8); RASSF1A - 24/70 (8/19, 6/20, 1/4, 1/2, 4/17, 4/8); CDH1 - 10/70 (0/19, 4/20,1/4, 1/2,3/17, 1/8). Using a panel of four genes, hypermethylation of one or more genes was found in 62/70 samples $(15 / 19,19 / 20,4 / 4,2 / 2,14 / 17,8 / 8)$. A panel of three genes omitting $R U N X 3$ detected hypermethylation in only 50/70 samples. No methylation was detected in the 10 healthy serum controls. Thus, RUNX3 can be detected in the serum of a high proportion of advanced cancers. This suggests that serum hypermethylation of RUNX3 is at least as, or possibly more sensitive a marker,
\end{abstract}

Correspondence to: Dr Yoshiaki Ito, Institute of Molecular and Cell Biology, 61 Biopolis Drive, Proteos, Singapore 138673

E-mail: itoy@imcb.a-star.edu.sg

${ }^{*}$ Contributed equally

Key words: promoter hypermethylation, serum, RUNX3, methylation-specific polymerase chain reaction than other tumor suppressor genes currently under investigation. Inclusion of $R U N X 3$ in gene panels can potentially increase the sensitivity of such panels for serum diagnosis of malignancies and warrants further study.

\section{Introduction}

There has been considerable interest recently in the area of epigenetic changes contributing to the process of carcinogenesis. Although it has been evident for years that germ line or somatic mutations can enhance the function of oncogenes or down-regulate the activity of tumor suppressor genes leading to the development of cancer, investigations have shown the presence of epigenetic changes in driving the development of tumors from the earliest to the latest stages (1). Molecular evidence of aberrant methylation of cytosine in promoter $\mathrm{CpG}$ islands causing transcriptional silencing of vital tumor suppressor genes in cancer cells has come to be recognized as an important feature of human cancer $(2,3)$. The methylation of tumor suppressor gene promoters contributes directly to the progression of some cancers (4). DNA methylation markers provide a unique combination of specificity, sensitivity, high information content and applicability to a wide variety of clinical specimens. Methylation markers are particularly suited for situations where sensitive detection is necessary, such as when tumor DNA is either scarce or diluted by excess normal DNA.

One of the most widely used methods for measuring methylation levels is methylation-specific polymerase chain reaction (MSP). MSP requires only a small quantity of DNA and is sensitive to $0.1 \%$ methylated alleles of a given $\mathrm{CpG}$ island locus (5). PCR-based methylation assays have been applied to the detection of tumor DNA in a variety of tissues and body fluids including serum, plasma, urine, sputum, stool, bile juice and lavage fluids (6). As current strategies for cancer detection are often costly, invasive and not well-defined, there remains a need to develop a reliable non-invasive test, preferably a simple venepuncture, for diagnostic purposes as well as for possible therapeutic monitoring. Hence using serum 

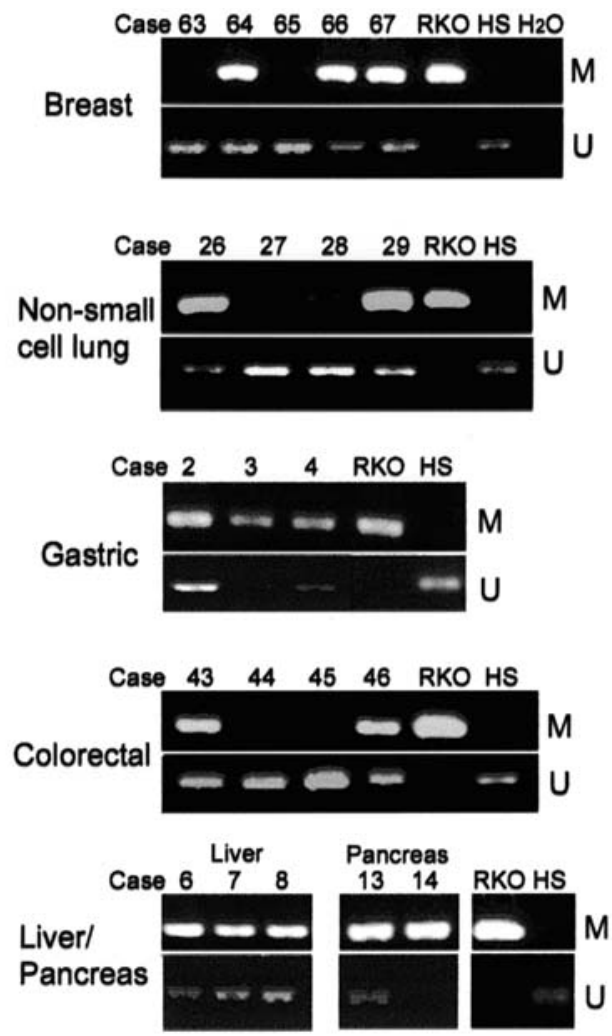

Figure 1. Representative gel electrophoresis pictures demonstrating aberrant methylation in breast, lung, gastric, liver, pancreas and colon serum samples. Lanes $\mathrm{M}$ and $\mathrm{U}$; amplified product with primers recognizing methylated and unmethylated sequences respectively. DNA from RKO cell line and healthy serum (HS); positive control for methylated and unmethylated forms respectively.

for this purpose is ideal. Furthermore, the ability of serum from blood samples to be re-used after storage is advantageous.

The presence of tumor DNA in serum was reported more than two decades ago (7). Early studies have shown the presence of $K$-ras and $p 53$ mutations in the serum of patients with colorectal, pancreas and breast cancer (8-10). More recently, the presence of gene promoter hypermethylation in serum DNA has also been demonstrated in breast, gastric, lung and liver carcinomas (11-14). In recent years, a CpG island hypermethylation profile of human primary tumors has emerged showing differential methylation dependent on tumor type $(15,16)$.

In this study, we sought to determine the feasibility and clinical correlations of detecting gene promoter hypermethylation utilizing the serum of patients with a variety of malignancies, namely breast, lung, gastric, pancreas, colorectal and liver, mainly focusing on the as yet unstudied tumor suppressor gene, $R U N X 3$.

Inclusion of 3 other tumor suppressor genes which have been shown reliably in other studies to be down-regulated by methylation, namely p16 (14,17,18), RASSF1A (19-21) and $C D H 1(22,23)$, was used to aid in confirming the presence and improving the sensitivity of tumor DNA detection.

\section{Materials and methods}

Sample collection. We examined 70 serum samples from patients who had histopathological evidence of cancer and radiological evidence of metastatic disease. Nineteen had breast, 20 had non-small cell lung, 4 had gastric, 2 had pancreatic, 17 had colorectal and 8 had confirmed hepatocellular carcinomas (HCCs). For the group of HCCs, they were diagnosed via histology or on a presumptive diagnosis based upon the following criteria (a) an $\alpha$-fetoprotein (AFP) level $>500 \mathrm{ng} / \mathrm{dl}$ (b) prior computed tomography or magnetic resonance imaging scans of the liver consistent with HCCs. Peripheral blood $(5 \mathrm{ml})$ was obtained at the time of diagnosis before chemotherapy or any other form of treatment was instituted for $>50 \%$ of the samples. For the remaining samples, their last cycle of chemotherapy was administered at least a month earlier, they were diagnosed radiologically to have progressed since then and were currently on conservative management. Serum samples from ten normal, healthy patients with no known cancer were used as controls. The study protocol was approved by the Institutional Review Board and all patients gave informed consent for the collection of blood samples. Serum was isolated by centrifugation at $3000 \mathrm{rpm}$ and $4^{\circ} \mathrm{C}$ for $10 \mathrm{~min}$ and stored at $-80^{\circ} \mathrm{C}$ until further processing.

DNA extraction. Genomic DNA from these samples was isolated using the QIAamp DNA Blood Mini Kit (Qiagen, Hilden, Germany) with certain modifications. $200 \mu 1$ of sample was used together with $40 \mu 1$ of Proteinase K, $200 \mu 1$ of PBS and $1 \mu \mathrm{g}$ of salmon sperm DNA. After incubating at $56^{\circ} \mathrm{C}$ for $1 \mathrm{~h}$, the genomic DNA was eluted using $100 \mu \mathrm{l}$ of $0.5 \mathrm{X}$ AE buffer (Qiagen). To enhance efficacy, the DNA extraction was carried out 6 months or earlier after sample collection.

Bisulfite treatment and MSP. The extracted DNA was treated with sodium bisulfite using the CpGenome DNA Modification kit (Chemicon, Temecula, CA), converting all unmethylated, but not methylated, cytosine to uracil. All bisulfite-modified DNA was resuspended in $20 \mu 1$ of TE buffer [10 mmol/l Tris-0.1 mmol/l EDTA (pH 7.5)] and stored at $-20^{\circ} \mathrm{C}$ until subsequent MSP. PCR primers distinguishing between methylated and unmethylated DNA for RUNX3 were used, the primer sequences being $\mathrm{S}$ (sense): 5'-GCGGTAAGATGGG CGAGAATA-3', AS (antisense): 5'-CACGAACTCGCCTA CGTAATC-3' and S: 5'- TGGTAAGATGGGTGAGAATA3', AS: 5'-CACAAACTCACCTACATAATCC-3' respectively. The primer sequences of $p 16$ (5), RASSF $1 A$ (24) and $C D H 1$ (25), annealing temperatures and the expected PCR product sizes had all been previously studied and can be found in the report referenced after each gene. For PCR amplification, $2.5 \mu \mathrm{l}$ of bisulfite-modified DNA was added in a final volume of $25 \mu \mathrm{l}$ of PCR mixture containing 10X PCR buffer, $10 \mathrm{mM}$ each deoxynucleotide triphosphates, $10 \mu \mathrm{M}$ each primers and $0.125 \mu 1$ each of HotStarTaq (Qiagen). PCR amplification of template DNA was performed under the following conditions: $95^{\circ} \mathrm{C}$ for $10 \mathrm{~min}$; 55 cycles (50 cycles only for $R U N X 3$ ) of $95^{\circ} \mathrm{C}$ for $15 \mathrm{sec}$, the specific annealing temperature for each gene $\left(60^{\circ} \mathrm{C} / 56^{\circ} \mathrm{C}\right.$ for methylated/unmethylated $\left.R U N X 3\right)$ for $30 \mathrm{sec}$ and $72^{\circ} \mathrm{C}$ for $20 \mathrm{sec}$. PCR products $(5 \mu \mathrm{l})$ were loaded onto a $2 \%$ non-denaturing agarose gel together with a 100-bp ladder, stained with ethidium bromide and visualized under UV illumination. The sample was scored as methylated when there was a visible band on the gel with methylated primers and 


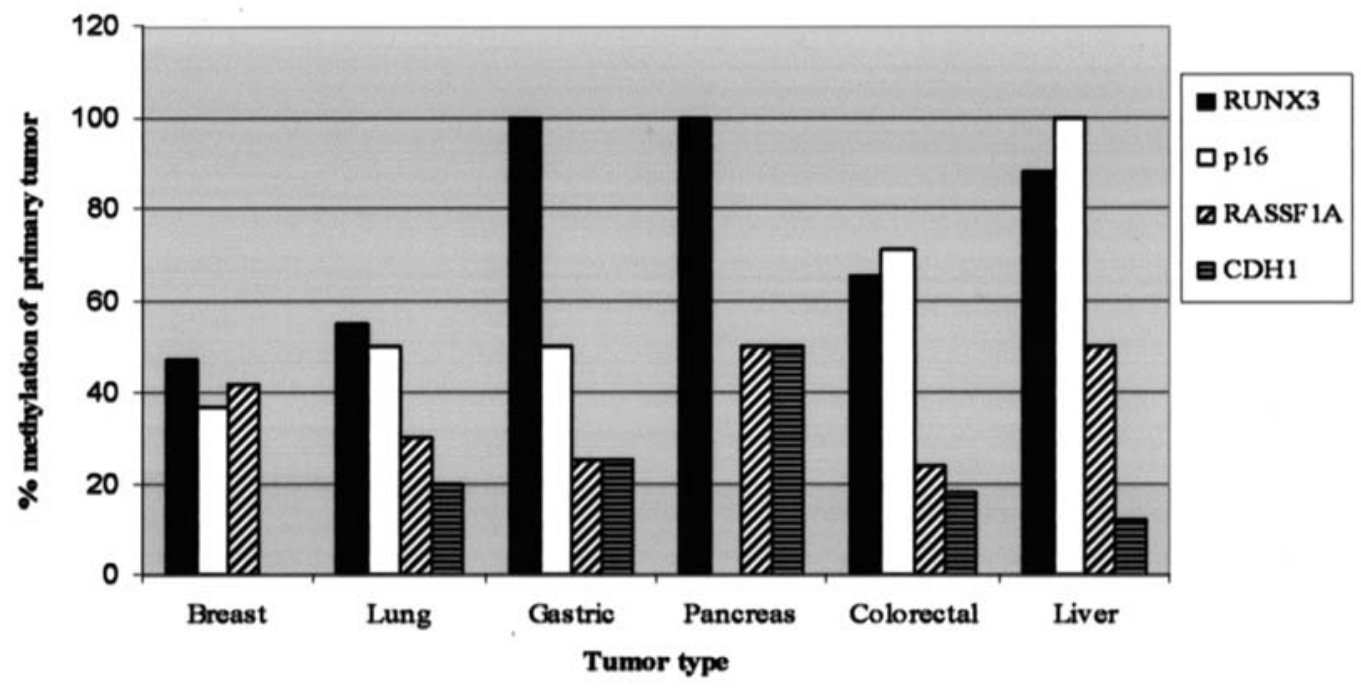

Figure 2. Methylation detection data of the various tumor types for RUNX3,p16, RASSF1A and CDH1.

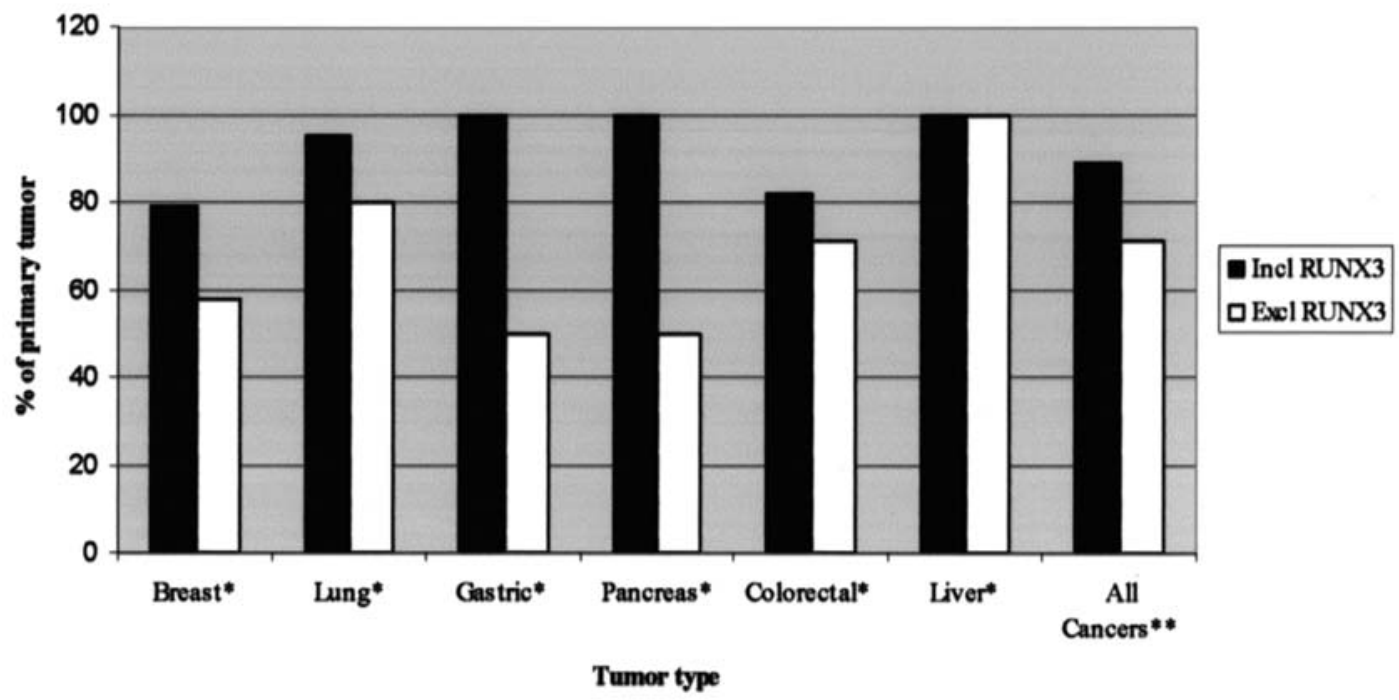

Figure 3. Percentage of 'each individual cancer' and 'all cancers' having at least one hypermethylated gene using $p 16, R A S S F 1 A$ and $C D H 1$ including or excluding $R U N X 3$. * p-value not significant for association of hypermethylation for $p 16, R A S S F 1 A$ and $C D H 1$ with or without $R U N X 3$, ${ }^{* *} \mathrm{p}=0.01$ for association of hypermethylation for $p 16, R A S S F 1 A$ and $C D H 1$ with or without $R U N X 3$ considering all cancers collectively.

similarly for unmethylated primer sets. Representative results of methylation analysis by MSP for RUNX3 are shown in Fig. 1.

Statistical analysis. The methylation status of the genes were tested for association with gender, smoking history and anatomical sites of metastases using the Chi-square test, while differences in sensitivity of cancer detection rate with and without RUNX3 was analyzed by a 2 -sample proportion test (SPSS 14.0, SPSS Inc.). The number of methylated genes were also assessed for correlation with age and survival duration of the patients using polyserial correlation coefficient (LISREL 8.72, Scientific Software International, Inc.). All tests were conducted at $5 \%$ significance level.

\section{Results}

Patient and tumor characteristics. A total of 70 peripheral blood samples were collected from patients with metastatic breast, non-small cell lung, gastric, pancreatic, colorectal and hepatocellular cancers from December 2004 to May 2006 under the Institutional Review Board guidelines. In total, we obtained 19 breast, 20 non-small cell lung, 4 gastric, 2 pancreatic, 17 colorectal, and 8 liver serum samples. Of the patients 38/70 (54\%) were chemonaive at the point of blood sampling and 32/70 (46\%) were free from chemotherapy for at least a month and had documented progressive disease since then.

Methylation status of four genes. The incidence of promoter hypermethylation of RUNX3 was detected in the serum of $44 / 70(62.9 \%)$ of patients; comparatively for $p 16,39 / 70$ (55.7\%); RASSF1A 24/70 (34.3\%) and CDH1 10/70 (14.3\%). The frequency of hypermethylation of an individual gene in relation to individual cancer groups are summarized in Fig. 2 and Table I. Using a panel of four genes, aberrant methylation in one or more tumor-related genes was detected in the serum of $62 / 70(88.6 \%)$ cancer patients. A panel of only three genes 
Table I. Frequency of promoter hypermethylation of $R U N X 3, p 16, R A S S F 1 A$ and $C D H 1$ in sera $(\mathrm{n}=70)$.

\begin{tabular}{lcccccc}
\hline Gene & $\begin{array}{c}\text { Breast } \\
(\mathrm{n}=19)\end{array}$ & $\begin{array}{c}\text { Non-small cell lung } \\
(\mathrm{n}=20)\end{array}$ & $\begin{array}{c}\text { Gastric } \\
(\mathrm{n}=4)\end{array}$ & $\begin{array}{c}\text { Pancreas } \\
(\mathrm{n}=2)\end{array}$ & $\begin{array}{c}\text { Colorectal } \\
(\mathrm{n}=17)\end{array}$ & $\begin{array}{c}\text { Liver } \\
(\mathrm{n}=8)\end{array}$ \\
\hline RUNX3 & $9(47 \%)$ & $11(55 \%)$ & $4(100 \%)$ & $2(100 \%)$ & $11(65 \%)$ & $7(88 \%)$ \\
p16 & $7(37 \%)$ & $10(50 \%)$ & $2(50 \%)$ & 0 & $12(71 \%)$ & $8(100 \%)$ \\
RASSF1A & $8(42 \%)$ & $6(30 \%)$ & $1(25 \%)$ & $1(50 \%)$ & $4(24 \%)$ & $4(50 \%)$ \\
CDH1 & 0 & $4(20 \%)$ & $1(25 \%)$ & $1(50 \%)$ & $3(18 \%)$ & $1(12 \%)$ \\
\hline
\end{tabular}

omitting RUNX3 detected hypermethylation in only 50/70 $(71.4 \%)$ of the samples. When comparing the sensitivity of the cancer detection rate with and without $R U N X 3$, considering all the samples together regardless of cancer types, the percentage of patients having at least one hypermethylated gene using only $p 16, R A S S F 1 A$ and $C D H 1$ was significantly different from that of including $R U N X 3$ to the panel of genes $(\mathrm{p}=0.01)$. This was not observed in the individual cancer types, which was probably due to the small sample size (Fig. 3). No methylated templates of the four genes were detected by MSP in all 10 healthy sera. There were 2 nonspecific bands for healthy serum for RASSF1A.

Correlations with clinical parameters. We correlated the methylation status of each of the genes with clinical characteristics from all the cancer patients. There was no significant association between the methylation status of each gene and clinical parameters including age, gender, distant metastases, smoking history and survival.

\section{Discussion}

The abnormal hypermethylation patterns of promoter site DNA causing gene silencing in cancer cells plays a pivotal role in tumorigenesis. The importance of promoter hypermethylation has been illuminated by the ability of demethylation drugs such as 5-azacytidine to reactivate the affected genes and restore production of the corresponding protein in cultured cancer cells (26).

One of the most widely used techniques for detecting and measuring methylation levels is MSP of which the level of sensitivity of conventional MSP can reach 1:1000 (5). Methylated serum DNA is a useful marker for cancer detection as serum is a readily accessible body fluid. DNA unlike mRNA is a stable molecule offering greater test stability and DNA methylation can be analyzed quantitatively. The mechanism leading to the presence of free tumor DNA in the serum remains unclear but may be related to cellular turnover, necrosis or apoptosis (27). On the other hand, serum tumor DNA may also originate from cells that have left the primary site and invaded the circulation, but are not yet capable of distant site metastases (28). However, aberrant methylation in the serum DNA has been reported to be detected more frequently in those who have developed distant metastases (28).

In recent years, the growing list of genes silenced by hypermethylation has given us ample opportunity to examine their role in various malignancies. In this present study, we determined the frequency of promoter hypermethylation, mainly focusing on $R U N X 3$, as it had not been studied in serum yet. We included 3 other established genes; p16, RASSF $1 A$ and $C D H 1$ which have shown moderately high methylation frequencies in previous studies as detailed below. Epigenetic inactivation of these different genes may affect all of the molecular pathways involved in cell immortalization and transformation (15).

RUNX3 has a current and relevant role in carcinogenesis. Transforming growth factor- $\beta$ (TGF- $\beta$ ) is a multifactorial growth factor that is crucial in many developmental and physiological processes. Polyomavirus enhancer binding protein/core binding factor (PEBP2/CBF) is a heterodimeric transcription factor composed of $\alpha$ and $\beta$ subunits and forms an important target for TGF- $ß$ superfamily signaling essential for mammalian development (29). The $\alpha$ subunit contains a conserved region known as the Runt domain required for DNA binding and dimerization with the $B$ subunit. Three mammalian runt-related $\alpha$ subunit genes exist, namely RUNX1/AML1, $R U N X 2 / C B F A-1$ and $R U N X 3 / P E B P 2 \alpha C$, the former 2 genes being essential for granulocytic differentiation and osteogenesis respectively (29-31). Each $R U N X$ forms complexes with Smad2 and Smad3 that transmit TGF-B/activin signals (32) .

$R U N X 3$ gene is located on human chromosome $1 \mathrm{p} 36$, where high frequency loss of heterozygosity (LOH) has been detected in various cancers. Thus RUNX3 may be a tumor suppressor candidate in cancer development. This relationship between $R U N X 3$ and carcinogenesis has already been extensively studied in the context of gastric cancer where it was found that 45-60\% of human gastric cancer cells do not express $R U N X 3$ due to hemizygous deletion and hypermethylation of the RUNX3 exon 1 region (31). Tumorigenicity of human gastric cancer cell lines was found to be inversely related to the level of RUNX3 expression, a mutation (R122C) within the Runt domain abolishing the tumor-suppressive effect of $R U N X 3$ (31). These results demonstrate that $R U N X 3$ plays a role as a tumor suppressor gene in gastric carcinogenesis. Furthermore, RUNX3 expression has also been reported to be lost in the range of $19-50 \%$ of lung cancer cell lines and tissue samples (33-35), 70\% of bile duct cancer cell lines, $75 \%$ of pancreatic cancer cell lines (36), 40-80\% of liver cancer cell lines and tissue $(37,38)$ and $50 \%$ of breast cancer tissue (39) due to hypermethylation of the $\mathrm{CpG}$ islands. Sporadic colon cancer associated with RUNX3 methylation has also been reported in approximately $30-50 \%$ of tissue samples (40). The frequency of RUNX3 in cancer serum has not been reported. 
These data suggest that RUNX3 plays an important part in various types of cancers. Based on these promising results, we thought that methodogically it would be an ideal approach to analyze RUNX3 with blood samples of patients with cancer. With regards to technological issues such as sample preparation, assay design and primer selection, we have attempted to improve and optimize the conditions in order to obtain the best possible experimental conditions. Our results were comparable with methylation frequencies obtained from cell lines and tissue samples in the other studies as previously mentioned. The higher than expected percentages for gastric and pancreatic patients were possibly due to small sample sizes.

Since its discovery as a cyclin-dependent kinase inhibitor (CDKI) in 1993, the tumor suppressor p16 located on chromosome 9p21 has gained widespread importance in cancer. Loss of function of $p 16$ occurs in at least three ways: homozygous deletion, methylation of the promoter and point mutation (the first two mechanisms comprising the majority of inactivation events in most primary tumors). p16 is a major target in carcinogenesis, rivaled in frequency only to that of the p53 tumor suppressor gene. Its mechanism of action as a CDKI has been elucidated and involves binding to and inactivating the cyclin-dependent kinase 4 (or 6) complex and thus rendering the retinoblastoma protein inactive. This effect blocks the transcription of important cell-cycle regulatory proteins and results in cell-cycle arrest (41). Our results for lung, gastric, colorectal and liver were comparable to, or even better in the case of breast, to previous quoted percentages $(13,14,42-44)$. The small sample number for pancreatic cancer specimens possibly limited our ability to adequately detect methylation.

A new 3p21.3 tumor suppressor gene, the Ras association domain family $1 \mathrm{~A}$ gene (RASSF 1A) from a minimal $120 \mathrm{~kb}$ region defined by overlapping homozygous deletions in lung and breast cancers has also been recently identified $(19,45,46)$. RASSF 1A may participate in the DNA damage response or in DNA damage-induced regulation of other cell signaling events $(45,47)$. In our study, we observed a methylation rate of $\sim 20-50 \%$ in all our cancer groups.

CDH1 (E-cadherin) is localized on chromosome 16q22 and down-regulation via methylation of the promoter region is observed in a wide variety of tumors from epithelial cells, hence its role in promoting cellular carcinogenesis. E-cadherin mediates cell-cell adhesion by association with intracellular molecules of $\alpha, \beta$, and $\gamma$-catenins (48). Reduction of $E$-cadherin induces cell mobility and promotes tumor cell invasion (49). In this study, we generally did not find a high proportion of methylation among our specimens. Although we did not detect any $C D H 1$ methylation for the breast samples, 15/19 (79\%) had methylation of at least one of the three remaining genes.

It is important to note that certain tumor suppressor genes taken alone such as RUNX3 or pl6 in hepatocellular carcinoma appear to give good detection frequencies in our study. Although this is suggestive of a possible histopathological correlation, further studies which include a panel of methylated markers are needed in order to increase the specificity.

Using RUNX3 as a candidate gene in our panel increased the methylation detection frequency by $17 \%$. Although further evaluation is essential in a larger study, the results of this study indicate the substantial usefulness of RUNX3 in combination with other tumor suppressor genes for the detection of various malignancies as it appears to increase the sensitivity over and above other more well-established tumor suppressor genes. It has been shown that the loss of expression of RUNX3 increases from the early stages of gastric carcinomas from $40 \%$ to almost $90 \%$ as cancer stage progresses (31). Thus MSP for RUNX3 may also prove to be a powerful diagnostic and prognostic tool for early detection of neoplastic and pre-neoplastic states for example intestinal metaplasia and liver cirrhosis in the future. Potential therapeutic applications are also possible, such as reactivation of RUNX3 tumor suppressor genes in established tumors. Therefore, there is scope for further studies into the utility of RUNX3 as a promising diagnostic and prognostic marker as well as its potential clinical applications in the future.

\section{References}

1. Herman JG and Baylin SB: Gene silencing in cancer in association with promoter hypermethylation. N Engl J Med 349: 2042-2054, 2003.

2. Jones PA and Baylin SB: The fundamental role of epigenetic events in cancer. Nat Rev Genet 3: 415-428, 2002.

3. Esteller M: $\mathrm{CpG}$ island hypermethylation and tumor suppressor genes: a booming present, a brighter future. Oncogene 21: 5427-5440, 2002.

4. Jones PA and Laird PW: Cancer epigenetics comes of age. Nat Genet 21: 163-167, 1999.

5. Herman JG, Graff JR, Myohanen S, Nelkin BD and Baylin SB: Methylation-specific PCR: a novel PCR assay for methylation status of CpG islands. Proc Natl Acad Sci USA 93: 9821-9826, 1996.

6. Cottrell SE and Laird PW: Sensitive detection of DNA methylation. Ann NY Acad Sci 983: 120-130, 2003.

7. Leon SA, Shapiro B, Sklaroff DM and Yaros MJ: Free DNA in the serum of cancer patients and the effect of therapy. Cancer Res 37: 646-650, 1977.

8. Hibi K, Robinson CR, Booker S, Wu L, Hamilton SR, Sidransky D and Jen J: Molecular detection of genetic alterations in the serum of colorectal cancer patients. Cancer Res 58: 1405-1407, 1998.

9. Silva JM, Dominguez G, Garcia JM, Gonzalez R, Villanueva MJ, Navarro F, Provencio M, San Martin S, Espana P and Bonilla F: Presence of tumor DNA in plasma of breast cancer patients: clinicopathological correlations. Cancer Res 59: 3251-3256, 1999.

10. Mulcahy HE, Lyautey J, Lederrey C, qi Chen X, Anker P, Alstead EM, Ballinger A, Farthing MJ and Stroun M: A prospective study of K-ras mutations in the plasma of pancreatic cancer patients. Clin Cancer Res 4: 271-275, 1998.

11. Dulaimi E, Hillinck J, Ibanez de Caceres I, Al-Saleem T and Cairns P: Tumor suppressor gene promoter hypermethylation in serum of breast cancer patients. Clin Cancer Res 10: 6189-6193, 2004.

12. Kanyama Y, Hibi K, Nakayama H, Kodera Y, Ito K, Akiyama S and Nakao A: Detection of p16 promoter hypermethylation in serum of gastric cancer patients. Cancer Sci 94: 418-420, 2003.

13. Esteller M, Sanchez-Cespedes M, Rosell R, Sidransky D, Baylin SB and Herman JG: Detection of aberrant promoter hypermethylation of tumor suppressor genes in serum DNA from non-small cell lung cancer patients. Cancer Res 59: 67-70, 1999.

14. Wong IH, Lo YM, Zhang J, Liew CT, Ng MH, Wong N, Lai PB, Lau WY, Hjelm NM and Johnson PJ: Detection of aberrant p16 methylation in the plasma and serum of liver cancer patients. Cancer Res 59: 71-73,1999.

15. Esteller M, Corn PG, Baylin SB and Herman JG: A gene hypermethylation profile of human cancer. Cancer Res 61: 3225-3229, 2001.

16. Costello JF, Fruhwald MC, Smiraglia DJ, Rush LJ, Robertson GP, Gao X, Wright FA, Feramisco JD, Peltomaki P, Lang JC, Schuller DE, Yu L, Bloomfield CD, Caligiuri MA, Yates A, Nishikawa R, Su Huang H, Petrelli NJ, Zhang X, O'Dorisio MS, Held WA, Cavenee WK and Plass C: Aberrant CpG island methylation has non-random and tumor-type-specific patterns. Nat Genet 24: 132-138, 2000. 
17. Krassenstein R, Sauter E, Dulaimi E, Battagli C, Ehya H, Klein-Szanto A and Cairns P: Detection of breast cancer in nipple aspirate fluid by $\mathrm{CpG}$ island hypermethylation. Clin Cancer Res 10: 28-32, 2004.

18. Jarmalaite S, Kannio A, Anttila S, Lazutka JR and Husgafvel-Pursiainen K: Aberrant p16 promoter methylation in smokers and former smokers with non-small cell lung cancer. Int J Cancer 106: 913-918, 2003.

19. Burbee DG, Forgacs E, Zochbauer-Muller S, Shivakumar L, Fong K, Gao B, Randle D, Kondo M, Virmani A, Bader S, Sekido Y, Latif F, Milch grub S, Toyooka S, Gazdar AF, Lerman MI, Zabarovsky E, White M and Minna JD: Epigenetic inactivation of RASSF1A in lung and breast cancers and malignant phenotype suppression. J Natl Cancer Inst 93: 691-699, 2001.

20. Byun DS, Lee MG, Chae KS, Ryu BG and Chi SG: Frequent epigenetic inactivation of RASSF1A by aberrant promoter hypermethylation in human gastric adenocarcinoma. Cancer Res 61: 7034-7038, 2001

21. Wagner KJ, Cooper WN, Grundy RG, Caldwell G, Jones C, Wadey RB, Morton D, Schofield PN, Reik W, Latif F and Maher ER: Frequent RASSF1A tumor suppressor gene promoter methylation in Wilms' tumor and colorectal cancer. Oncogene 21: 7277-7282, 2002.

22. Tamura G, Yin J, Wang S, Fleisher AS, Zou T, Abraham JM, Kong D, Smolinski KN, Wilson KT, James SP, Silverberg SG, Nishizuka S, Terashima M, Motoyama T and Meltzer SJ: Ecadherin gene promoter hypermethylation in primary human gastric carcinomas. J Natl Cancer Inst 92: 569-573, 2000.

23. Matsumura T, Makino R and Mitamura K: Frequent downregulation of E-cadherin by genetic and epigenetic changes in the malignant progression of hepatocellular carcinomas. Clin Cancer Res 7: 594-599, 2001.

24. Honorio S, Agathanggelou A, Schuermann M, Pankow W, Viacava P, Maher ER and Latif F: Detection of RASSF1A aberrant promoter hypermethylation in sputum from chronic smokers and ductal carcinoma in situ from breast cancer patients. Oncogene 22: 147-150, 2003.

25. Horikawa Y, Sugano K, Shigyo M, Yamamoto H, Nakazono M, Fujimoto H, Kanai Y, Hirohashi S, Kakizoe T, Habuchi T and Kato T: Hypermethylation of an E-cadherin (CDH1) promoter region in high grade transitional cell carcinoma of the bladder comprising carcinoma in situ. J Urol 169: 1541-1545, 2003.

26. Merlo A, Herman JG, Mao L, Lee DJ, Gabrielson E, Burger PC, Baylin SB and Sidransky D: 5' CpG island methylation is associated with transcriptional silencing of the tumor suppressor p16/CDKN2/MTS1 in human cancers. Nat Med 1: 686-692,1995.

27. Wong IH, Lo YM, Yeo W, Lau WY and Johnson PJ: Frequent p15 promoter methylation in tumor and peripheral blood from hepatocellular carcinoma patients. Clin Cancer Res 6: 3516-3521, 2000.

28. Sanchez-Cespedes M, Esteller M, Wu L, Nawroz-Danish H, Yoo GH, Koch WM, Jen J, Herman JG and Sidransky D: Gene promoter hypermethylation in tumors and serum of head and neck cancer patients. Cancer Res 60: 892-895, 2000.

29. Okuda T, van Deursen J, Hiebert SW, Grosveld G and Downing JR: AML1, the target of multiple chromosomal translocations in human leukemia, is essential for normal fetal liver hematopoiesis. Cell 84: 321-330, 1996.

30. Lee B, Thirunavukkarasu K, Zhou L, Pastore L, Baldini A, Hecht J, Geoffroy V, Ducy P and Karsenty G: Missense mutations abolishing DNA binding of the osteoblast-specific transcription factor OSF2/CBFA1 in cleidocranial dysplasia. Nat Genet 16: 307-310, 1997.

31. Li QL, Ito K, Sakakura C, Fukamachi H, Inoue K, Chi XZ, Lee KY, Nomura S, Lee CW, Han SB, Kim HM, Kim WJ, Yamamoto H, Yamashita N, Yano T, Ikeda T, Itohara S, Inazawa J, Abe T, Hagiwara A, Yamagishi H, Ooe A, Kaneda A, Sugimura T, Ushijima T, Bae SC and Ito Y: Causal relationship between the loss of RUNX3 expression and gastric cancer. Cell 109: 113-124, 2002.
32. Hanai J, Chen LF, Kanno T, Ohtani-Fujita N, Kim WY, Guo WH, Imamura T, Ishidou Y, Fukuchi M, Shi MJ, Stavnezer J, Kawabata M, Miyazono K and Ito Y: Interaction and functional cooperation of PEBP2/CBF with Smads. Synergistic induction of the immunoglobulin germline Calpha promoter. J Biol Chem 274: 31577-31582, 1999 .

33. Li QL, Kim HR, Kim WJ, Choi JK, Lee YH, Kim HM, Li LS, Kim H, Chang J, Ito Y, Youl Lee K and Bae SC: Transcriptional silencing of the RUNX3 gene by CpG hypermethylation is associated with lung cancer. Biochem Biophys Res Commun 314: 223-228, 2004.

34. Sato K, Tomizawa Y, Iijima H, Saito R, Ishizuka T, Nakajima T and Mori M: Epigenetic inactivation of the RUNX3 gene in lung cancer. Oncol Rep 15: 129-135, 2006.

35. Yanagawa N, Tamura G, Oizumi H, Takahashi N, Shimazaki Y and Motoyama T: Promoter hypermethylation of tumor suppressor and tumor-related genes in non-small cell lung cancers. Cancer Sci 94: 589-592, 2003.

36. Wada M, Yazumi S, Takaishi S, Hasegawa K, Sawada M, Tanaka H, Ida H, Sakakura $\mathrm{C}$, Ito $\mathrm{K}$, Ito $\mathrm{Y}$ and Chiba $\mathrm{T}$ : Frequent loss of RUNX3 gene expression in human bile duct and pancreatic cancer cell lines. Oncogene 23: 2401-2407, 2004.

37. Mori T, Nomoto S, Koshikawa K, Fujii T, Sakai M, Nishikawa Y, Inoue S, Takeda S, Kaneko T and Nakao A: Decreased expression and frequent allelic inactivation of the RUNX3 gene at $1 \mathrm{p} 36$ in human hepatocellular carcinoma. Liver Int 25: 380-388, 2005

38. Park WS, Cho YG, Kim CJ, Song JH, Lee YS, Kim SY, Nam SW, Lee SH, Yoo NJ and Lee JY: Hypermethylation of the RUNX3 gene in hepatocellular carcinoma. Exp Mol Med 37: 276-281, 2005 .

39. Lau QC, Raja E, Salto-Tellez M, Liu Q, Ito K, Inoue M, Putti TC, Loh M, Ko TK, Huang C, Bhalla KN, Zhu T, Ito Y and Sukumar S: RUNX3 Is Frequently Inactivated by Dual Mechanisms of Protein Mislocalization and Promoter Hypermethylation in Breast Cancer. Cancer Res 66: 6512-6520, 2006.

40. Imamura Y, Hibi K, Koike M, Fujiwara M, Kodera Y, Ito K and Nakao A: RUNX3 promoter region is specifically methylated in poorly-differentiated colorectal cancer. Anticancer Res 25: 2627-2630, 2005

41. Liggett WH, Jr. and Sidransky D: Role of the p16 tumor suppressor gene in cancer. J Clin Oncol 16: 1197-1206, 1998

42. Lee TL, Leung WK, Chan MW, Ng EK, Tong JH, Lo KW, Chung SC, Sung JJ and To KF: Detection of gene promoter hypermethylation in the tumor and serum of patients with gastric carcinoma. Clin Cancer Res 8: 1761-1766, 2002.

43. Hu XC, Wong IH and Chow LW: Tumor-derived aberrant methylation in plasma of invasive ductal breast cancer patients: clinical implications. Oncol Rep 10: 1811-1815, 2003.

44. Zou HZ, Yu BM, Wang ZW, Sun JY, Cang H, Gao F, Li DH, Zhao R, Feng GG and Yi J: Detection of aberrant p16 methylation in the serum of colorectal cancer patients. Clin Cancer Res 8: 188-191, 2002.

45. Dammann R, Li C, Yoon JH, Chin PL, Bates S and Pfeifer GP: Epigenetic inactivation of a RAS association domain family protein from the lung tumor suppressor locus 3p21.3. Nat Genet 25: 315-319, 2000.

46. Agathanggelou A, Honorio S, Macartney DP, Martinez A, Dallol A, Rader J, Fullwood P, Chauhan A, Walker R, Shaw JA, Hosoe S, Lerman MI, Minna JD, Maher ER and Latif F: Methylation associated inactivation of RASSF1A from region 3 p21.3 in lung, breast and ovarian tumors. Oncogene 20: 1509-1518, 2001

47. Kim ST, Lim DS, Canman CE and Kastan MB: Substrate specificities and identification of putative substrates of ATM kinase family members. J Biol Chem 274: 37538-37543, 1999.

48. Takeichi M: Cadherin cell adhesion receptors as a morphogenetic regulator. Science 251: 1451-1455, 1991.

49. Mareel M, Boterberg T, Noe V, Van Hoorde L, Vermeulen S, Bruyneel $\mathrm{E}$ and Bracke M: E-cadherin/catenin/cytoskeleton complex: a regulator of cancer invasion. J Cell Physiol 173: 271-274, 1997. 